\title{
Analysis the Impact of Organizational Culture and Motivation on Employee Performance with Employee Engagement as an Intervening Variable
}

\author{
Sebasthian Blegur ${ }^{1}$, Lia Amalia ${ }^{2}$ \\ Universitas Esa Unggul Jakarta ${ }^{1,2}$
}

\begin{abstract}
The implementation of bureaucratic reform is a must, given the current administration of the government is faced with the high demands of the community for improving government performance. Civil servants (PNS) in Indonesia consisting of 4.7 million are the driving force of the government bureaucracy must participate in fundamental changes towards good and clean governance. In relation to performance appraisal, in clause 75 of the ASN Law it is stated that the performance appraisal of civil servants aims to guarantee the objectivity of fostering civil servants based on performance planning at the individual level and level of units or organizational units by paying attention to targets, targets, results and benefits achieved, and the behavior of civil servants themselves is objective, measurable, accountable, participatory, and transparent. Based on Clause 4 PP No. 46 of 2011, the assessment of work performance of civil servants is divided into two elements, the first is the performance target of employees who make measurements in terms of quantity, quality, time and cost. Second, work habits dikut of service orientation. Organizational culture and motivation have an effect on employee engagement which will have an effect on employee performance. These three variables can affect the performance of employees, because if all three increase, it will have a good impact on employee performance. Employee performance is an important thing that needs to be considered in an organization / company. this research will be conducted on Dinas Pariwisata Kabupaten Alor. In Alor government Dinas Pariwisata is very important for the advancement of tourism and the creative economy in the city of Alor, so that it must have a good and effective employee performance so that Dinas Pariwisata Alot can create a destination tourism that is good and can be a tourist destination for tourists is at the same time able to create a creative economy in the form of selling souvenirs which are typical of Alor which later can be useful for the surrounding community in obtaining income. With the presence of Dinas Pariwisata Alor it is expected that later it can increase economic growth in Alor and be able to introduce the culture and beauty of Alor in areas outside Alor. The purpose of this research is to determine the effect of organizational culture and motivation on employee performance with employee engagement as an intervening variable. This research is quantitative research. The analytical method used in this study is Structural Equation Model (SEM). This study shows that good and high organizational culture can improve employee performance. High motivation in company/organization can improve employee performance. High employee engagement can improve employee performance. In this study employee engagement can mediate organizational culture and motivation because this study shows employee engagement affects employee performance.
\end{abstract}

Key words: Indonesia, Organization Culture, Motivation, Employee Engagement, Employee Performance

\section{INTRODUCTION}

In an effort to achieve optimal work results, organizations must take various ways to obtain high quality human resources where an employee must have an organizational culture, motivation, and employee engagement to support the performance of the organization's employees. Employees or human resources is one of the important assets contained in the organization. An organization must produce good and high-skilled performance to manage the organization as optimally as possible, employee performance is very important in its role in organizational development, but in its application the employee's performance is not always good, sometimes the employee's performance weakens and decreases. Especially the performance of employees in a government institution, government institutions are collective designations including the work of ministry organizations, Non-Departmental Government Institutions, secretariat of state high institutions, and other government institutions, both central and regional. The level of success of region is judged by how capable a region is in carrying out its duties in each government institution in the region, for that it requires employees with good performance to be able to achieve the vision and mission set out in a government institution.

The implementation of bureaucratic reform is a must, given the current administration of the government is faced with the high demands of the community for improving government performance. Civil servants (PNS) in Indonesia 


\section{International Advanced Research Journal in Science, Engineering and Technology}

Vol. 6, Issue 3, March 2019

consisting of 4.7 million are the driving force of the government bureaucracy must participate in fundamental changes towards good and clean governance. In relation to performance appraisal, in clause 75 of the ASN Law it is stated that the performance appraisal of civil servants aims to guarantee the objectivity of fostering civil servants based on performance planning at the individual level and level of units or organizational units by paying attention to targets, targets, results and benefits achieved, and the behavior of civil servants themselves is objective, measurable, accountable, participatory, and transparent. Based on Clause 4 PP No. 46 of 2011, the assessment of work performance of civil servants is divided into two elements, the first is the performance target of employees who make measurements in terms of quantity, quality, time and cost. Second, work habits dikut of service orientation. Organizational culture and motivation have an effect on employee engagement which will have an effect on employee performance. These three variables can affect the performance of employees, because if all three increase, it will have a good impact on employee performance.

Organizational culture factors, within an organization the organizational culture problems are inseparable from the internal environment of the organization, because the diversity that exists in the organization is as much as the number of individuals in the organization, so in the organization it is necessary to establish organizational culture that will create unity goals between individuals and other individuals so that a common goal is formed that will lead to the progress of the organization as desired. There are many attributes of organizational culture that have a significant and positive effect on employee performance, organizational culture as a vital relationship between organizational culture and performance, through strong and in-depth observations, beliefs, norms, employee attitudes and all relevant aspects of organizational culture have an impact on company performance. (Jassim et. al, 2013). Performance is influenced by strong motivation from employees to work regularly and continuously to carry out the work assigned to them. Motivation from strong employees can improve employee performance in an agency / organization (Jiony et. al, 2015). In Alor government in Dinas Pariwisata, it is very important for the advancement of tourism and the creative economy in the city of Alor, so that it must have a good and effective employee performance so that Dinas Pariwisata Alor can create a destination tourism that is good and can be a tourist destination for tourists is at the same time able to create a creative economy in the form of selling souvenirs that are typical of Alor which later can be useful for the surrounding community in obtaining income. With the presence of the Dinas Pariwisata Alor, it is hoped that later it can increase economic growth in Alor and be able to introduce the culture and beauty of Alor in areas outside Alor.

This study further examines the initial research conducted by Siddhanta and Roy (2010) on organizational culture and employee performance. Furthermore, the researchers examined the effect of motivation on employee performance conducted by Zameer et. al. (2014). To enrich the literature review more deeply about the influence of organizational culture and motivation on employee performance, researchers developed from the research conducted by McLaughlin et. al. (2017) and Evangeline and Gopal (2016). This research is a development of previous research conducted by Sappe etl. Al (2016), but that distinguishes it from the research of Sappe et. al is the researcher adds employee performance as the dependent variable, then makes the motivation and organizational culture as independent variables. In the study conducted by Jiony and Mc Laughlin both used employee engagement as the dependent variable, while in this study the study used employee engagement as an intervening variable. Research on the influence of organizational culture and motivation on employee performance has been done, but there are differences in this study. In this study the author uses intervening variables, the intervening variable in this study has a function as a liaison between the independent variable and dependent, so that with this intervening variable the independent variable does not directly affect the dependent variable. The intervening variable used in this study is employee engagement.

The research conducted by Jiony et.al. (2015) used the same method with the method that researchers used, namely SEM, but researchers would use different software in processing data, researchers would use LISREL. In previous studies there were still many studies that used regression analysis, but in this study the authors used SEM (Structural Equation Modeling). The use of SEM analysis is intended to obtain a more perfect output model, through a series of evaluation models in its analysis. Another difference found in this study is that from some of the previous studies above, some use organizations / companies as research subjects. One example is research conducted by Fu, Satish and Deshpande (2014). This study conducted research on insurance offices in China., while in this study the researchers conducted research on one of the agencies in Alor Regency, the agency that was the subject of the research was employees who worked at the Office of Tourism and Creative Economy in Alor Regency.

\section{LITERATURE REVIEW}

Employee Performance: Robbins and Coulter (2012) define performance as an end result of an activity carried out. The dimensions and indicators contained in employee performance are (1) quality of work, this dimension shows neatness, accuracy, relevance of results by not ignoring the volume of work. Indicators in this dimension are neatness and accuracy, and work results; (2) quantity of work, showing the number of types of work carried out at one time so 


\section{International Advanced Research Journal in Science, Engineering and Technology}

Vol. 6, Issue 3, March 2019

that efficiency and effectiveness can be carried out in accordance with the objectives of the company. Indicators in this dimension are speed and ability; (3) work responsibilities, showing how much the employee is in accepting and carrying out his work, taking responsibility for the work results and the facilities and infrastructure used and his work behavior every day. Indicators in this dimension are the results of work and making decisions; (4) cooperation. Willingness of employees to participate with other employees vertically and horizontally both inside and outside the work so that the results of the work will be better. Indicators in this dimension are links of cooperation and compactness; (5) initiative, the ability of employees to create new ideas.

Organization Culture: Robbins \& Coulter (2012) defines organizational culture as values, principles, traditions, ways of working shared by members of the organization and influencing the way they act. According to Robbins \& Judge (2013) there are several indicators that can be used to measure employee performance in the Dinas Pariwisata Kabupaten Alor: innovation and risk taking, attention to detail, outcome orientation, people orientation, team orientation, aggressiveness, and stability innovation and risk taking: more to where employees are able to create new innovations in achieving organizational goals and able to bear the risks that exist in a job. Attetion to detail: more attention to details in the hope that workers will work in more detail, analysis, and on target. Outcome orientation: focus more on results or benefits, not only on the process of getting results. People orientation: pay attention to the influence or benefits of something that is produced to each party in the organization. Team orientation: the act of prioritizing work activities in organizations based on teams, not individuals. Aggresiveness: a situation where people tend to be more competitive. Stability: a situation where organizational activity emphasizes maintaining the status quo as opposed to development.

Motivation: Mathis and Jackson (2010) motivation plays a role in increasing desire in a person causing the person to take action. Someone takes action to achieve the goal, therefore motivation is the driver that directs the goal. The dimensions of work motivation are divided into 3 (three), namely: (1) dimensions of need for achievement, which are measured by two indicators, like challenges in work and enthusiasm for achievement; (2) dimensions of affiliate needs, this dimension is measured by 2 (two) indicators, has good relations with the organization and has good cooperation with colleagues; and (3) dimensions of the need for power, this dimension is measured by 2 (two) indicators, namely rewards and opportunities to expand power.

Employee Engagement: Marciano (2010) employee engagement is a high emotional and intellectual level relationship that is owned by employees in their work towards the company, their managers and coworkers who in turn influence it to give their business and work to their work more than expected, driven by their own desires. Employee engagement consists of 3 (three) dimensions, namely: (1) vigor, one of the three main components that refers to the level of energy needed for high work, fatigue, mental endurance during work and willingness and optimism even in the face of difficulties and challenges ; (2) dedication, emphasis on work, inspiration, pride, and enthusiasm in work; (3) absorption, referring to employees who are concentrated and happy in doing work, time passes quickly and is difficult for employees to release themselves from work. In working, employees tend to forget about things around them.

Relationship Between Variables and Hypothesis Development: In a study conducted by Jasim, Huq \& Maroof (2013), these findings significantly showed cultural positive and negative behavior had significant consequences for employees and performance. This study also confirmed that organizational culture is an open system approach that has independent and interactive. Strong organizational culture will affect the company's policies, organizational structure and other regulations, in the organization employees must know what their obligations are in various situations and conditions in accordance with instructions and guidelines that are reflected in the values adopted in the organization. H1: High organizational culture will improve employee performance.

Shahzadi et. al. (2014) in his research said that under motivation affects employee performance significantly and positively. In this study, it was also explained that rewards have a positive and significant relationship to employee motivation and performance, but not for the effectiveness of training, because the training provided to employees cannot be implemented in routine activities of employees and employees if this becomes ineffective. Motivation needs to get great attention for the organization in improving employee performance (Sappe et. Al, 2014). Motivation is the basic approach and the basic reason for employees to join, live and work effectively (Zameer et. Al, 2014). For this reason, management must know and understand effective ways to strengthen employee motivation. H2: High motivation will improve employee performance.

Sidhanta and Roy (2010) in their study said that organizational culture has a direct and positive impact on employee engagement. It is clear that employees prefer jobs that match their preferences and they will be motivated to be more involved with work that uses the competencies and skills they have (McLaughlin et. al., 2017). H3: Organizational culture can increase employee engagement. 


\section{International Advanced Research Journal in Science, Engineering and Technology}

Vol. 6, Issue 3, March 2019

Evangeline and Gopal (2016) in their study say that high motivation can increase employee engagement. Managerial implications in this study are that management needs to improve and coordinate policies, rules and procedures related to methods of increasing employee engagement to maintain employee motivation. This is because motivation has long been known as a very important factor for an organization, with good working conditions, interesting work, and a suitable salary will increase motivation, so that the resulting employee engagement will also increase. H4: High motivation can increase employee engagement.

Ahmed et. al (2011) in his research that employee engagement has a positive influence on employee performance, in this study explained that employee engagement is the key to improving performance. In addition to that effective employee engagement to increase commitment, so that later there will be a desire to achieve common goals and employee engagement will have an impact on overall performance. Organizations must focus on presenting a good environment for employees to work and promote programs that are able to improve relationships with colleagues.

H5: High employee engagement can improve employee performance.

Research Method: based on the hypothesis in the design of this study determind the variables used in the study. There are four variables: organization culture, motivation, employee engagement, and employee performance. Data collection was done by distributing questionnaires. The collected data was processed using descriptive and quantitative analysis tools. Analysis of the data used is the Structural Equation Model (SEM) and the computer program used is LISREL. The sample in this study were all employees who worked at Alor Regency Tourism Office.

\section{Structural Equation Model (SEM)}

Tabel 1: Analysis of the Goodness Fit

\begin{tabular}{|c|c|c|c|}
\hline No & Indicator & Value & Information \\
\hline \multirow{4}{*}{1} & Degree of Freedom & 242 & \multirow{4}{*}{ Good Fit } \\
\hline & Chi Square & 612,09 & \\
\hline & NCP & 490,09 & \\
\hline & Confidence Interval & 412,$54 ; 575,25$ & \\
\hline \multirow{3}{*}{2} & RMSEA & 0,061 & \multirow{3}{*}{ Good Fit } \\
\hline & Confidence Interval & 0,$02 ; 0,083$ & \\
\hline & P Value & 0,019 & \\
\hline \multirow{4}{*}{3} & ECVI Model & 4,96 & \multirow{4}{*}{ Good Fit } \\
\hline & ECVI Saturated & 7,01 & \\
\hline & ECVI Independence & 49,73 & \\
\hline & Confidence Interval & 4,$03 ; 6,35$ & \\
\hline \multirow[t]{6}{*}{4} & AIC Model & 600 & \multirow{6}{*}{ Good Fit } \\
\hline & AIC Saturated & 848,09 & \\
\hline & AIC Independence & 6015,90 & \\
\hline & CAIC Model & 1068,72 & \\
\hline & CAIC Saturated & 1741,21 & \\
\hline & CAIC Independence & 6107,20 & \\
\hline \multirow{6}{*}{5} & NFI & 0,92 & \multirow{6}{*}{ Good Fit } \\
\hline & CFI & 0,95 & \\
\hline & NNFI & 0,93 & \\
\hline & IFI & 0,91 & \\
\hline & RFI & 0,93 & \\
\hline & PNFI & 0,76 & \\
\hline 6 & Critical N & 146,91 & Marginal Fit \\
\hline \multirow{4}{*}{7} & Standardized RMR & 0,065 & \multirow{4}{*}{ Good Fit } \\
\hline & GFI & 0,95 & \\
\hline & AGFI & 0,93 & \\
\hline & PGFI & 0,67 & \\
\hline
\end{tabular}

Source: SEM test results 


\section{International Advanced Research Journal in Science, Engineering and Technology}

Vol. 6, Issue 3, March 2019

\section{RESULT AND DISCUSSION}

\section{Result}

In this study there are five hypotheses tested and based on the results of testing, the results obtained that the five existing hypotheses are supported by data stating that: good organizational culture can improve employee performance in an institution / organization, this can be seen through the acquisition of value t-value in testing this hypothesis is 2.43. Besides this hypothesis is also supported by previous research conducted by Jasim, Huq \& Maroof (2013) which says that organizational culture attributes have a positive influence on performance, which in this study explains how beliefs, norms, gestures of employees and all relevant aspects from organizational culture has an impact on performance. High motivation in employees can improve employee performance in an organization / institution, with this can be seen through the acquisition of t-value in testing this hypothesis, which is 3.37. This hypothesis is also supported by previous research conducted by Shahzadi et. al. (2014), Sappe et. al. (2014), and Zameer et. al. (2014) which states that motivation has a positive effect on employee performance, this is because motivation is the basic approach and the basic reason for employees to join, live and work effectively, for which management must know and understand effective ways to strengthen employee performance in the company or organization. Good organizational culture can increase employee engagement, this can be seen through the acquisition of t-value in testing this hypothesis, which is 3.37. This hypothesis is supported by a statement from McLaughlin et. al. (2017) who say that organizational culture has an influence on employee engagement, it is clear that employees prefer jobs that match their preferences and they will be motivated to be more involved with work that uses the competencies and skills they have.

High motivation to increase employee engagement, it can be seen through the acquisition value of the t-value in testing this hypothesis is 3.12. This hypothesis is supported by research conducted by Evangeline and Gopal (2016) wherein the study said that high motivation can increase employee engagement. This is because motivation has long been known as a very important factor for a company or organization and with good working conditions, interesting work, and a suitable salary will increase motivation, then the resulting employee engagement will also increase. High employee engagement can improve employee performance, this can be seen through the acquisition of t-value in this hypothesis testing, which is 7.18. This hypothesis is supported by research conducted by Ahmed et. al. (2011) who said that employee enagagement has a positive influence on employee performance, because effective employee engagement to improve commitment, so that later there will be a desire to achieve common goals and employee engagement will have an impact on overall employee performance The instrument used in this study has been tested in validity and reliability thus the results of Construct Reliability and Variance Extracted BO value of VE 0,78; M value is VE 0,56; KP value is VE 0,56; and EE value is VE 0,62. Goodness of fit, is where Chi Square $=637,11$; Degree of Freedom $=245 ; \mathrm{ECVI}=4,96 ; \mathrm{AIC}=600 ; \mathrm{CAIC}=1056,33 ;$ Critical $\mathrm{N}=146,47 ; \mathrm{RMR}=0,065 ;$ and $\mathrm{PGFI}=0,64$. Futhermore, this research produced value diagrams as in the following figure:

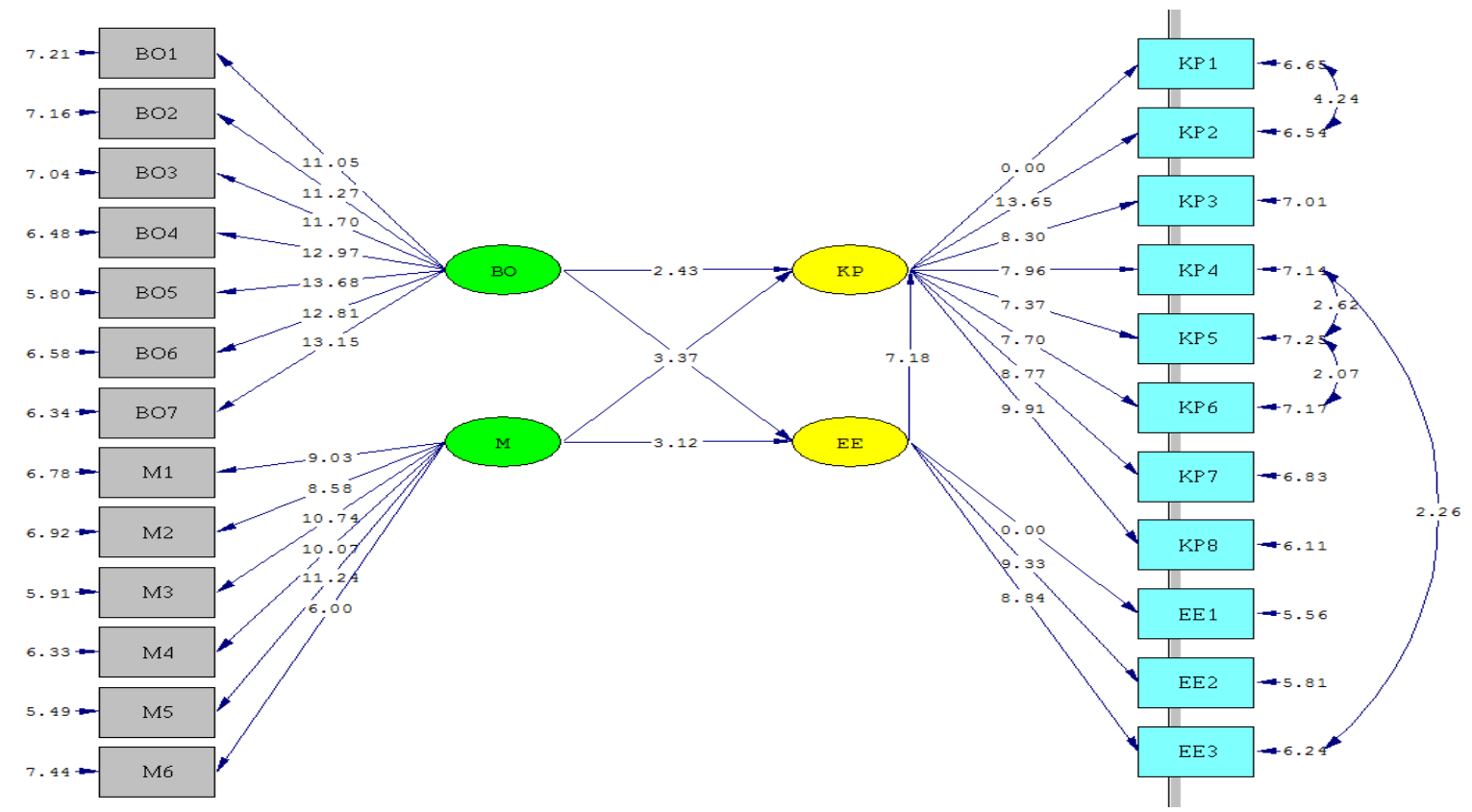

Figure 1 Path Diagram T - Value 


\section{International Advanced Research Journal in Science, Engineering and Technology}

Vol. 6, Issue 3, March 2019

Tabel 2: Research Model Hypothesis Testing

\begin{tabular}{|c|l|c|l|}
\hline $\mathbf{H}$ & \multicolumn{1}{|c|}{ Hypothesis } & t-value & \multicolumn{1}{|c|}{ Information } \\
\hline $\mathrm{H}_{1}$ & $\begin{array}{l}\text { Good organizational culture improves } \\
\text { employee performance. }\end{array}$ & 2,43 & $\begin{array}{l}\text { Data supports the } \\
\text { hypothesis }\end{array}$ \\
\hline $\mathrm{H}_{2}$ & $\begin{array}{l}\text { High motivation increases employee } \\
\text { performance. }\end{array}$ & 3,37 & $\begin{array}{l}\text { Data supports the } \\
\text { hypothesis }\end{array}$ \\
\hline $\mathrm{H}_{3}$ & $\begin{array}{l}\text { Good Organizational Culture } \\
\text { increases Employee Engagement. }\end{array}$ & 3,37 & $\begin{array}{l}\text { Data supports the } \\
\text { hypothesis }\end{array}$ \\
\hline $\mathrm{H}_{4}$ & $\begin{array}{l}\text { High motivation increases Employee } \\
\text { Engagement. }\end{array}$ & 3,12 & $\begin{array}{l}\text { Data supports the } \\
\text { hypothesis }\end{array}$ \\
\hline $\mathrm{H}_{5}$ & $\begin{array}{l}\text { High employee engagement increases } \\
\text { employee performance. }\end{array}$ & 7,18 & $\begin{array}{l}\text { Data supports the } \\
\text { hypothesis }\end{array}$ \\
\hline
\end{tabular}

Source: The results on data analysis tools.

\section{Discussion}

\section{Organizational Culture Has a Positive Effect on Improving Employee Performance}

In the results of testing the first hypothesis (H1), it was found that the results of the analysis support the H1 hypothesis, namely good organizational culture can improve employee performance. From the results of this test shows that Organizational Culture influences Employee Performance. Seen in the Path T-value diagram that Organizational Culture in this study uses 7 dimensions which include: Innovation and risk taking (BO1) of 11.05; Attention to detail (BO2) of 11.27; Outcome orientation (BO3) of 11.70; People orientation (BO4) of 12.97; Team orientation (BO5) of 13.68; Agressive (BO6) of 12.81; and Stability (BO7) of 13.15. These dimension values show that Team Orientation Organizational Culture has the highest value on Employee Performance.

The results of this study further corroborate the results of previous studies conducted by Jasim, Huq \& Maroof (2013) which say that organizational culture attributes have a positive influence on performance, which in this study explains how beliefs, norms, gestures of employees and all relevant aspects organizational culture has an impact on performance. Organizational culture and strong help organizational performance because creating an extraordinary level in employees and a strong organizational culture to help organizational performance because it provides the structure and control needed without having to rely on a rigid formal bureaucracy and which can suppress the growth of motivation and innovation.

High Motivation Increases Employee Performance.

In the results of testing the second hypothesis $(\mathrm{H} 2)$, it was found that the results of the analysis support the $\mathrm{H} 2$ hypothesis, namely high motivation can improve Employee Performance. From the results of this test shows that motivation affects employee performance. Seen in the Path t-value diagram (Figure 3.1) that motivation. in this study using 6 indicators which include: Liking challenges in work (M1) of 9.03; Enthusiasm for achievement (M2) is 8.58; Have a good relationship with the organization (M3) of 10.74; Having good cooperation (M4) of 10.07; Award (M5) of 11.24; and the opportunity to expand power (M6) is 6.00 . The indicator values show that the award motivation is the highest value for employee performance.

The results of this study further strengthen the research conducted by Shahzadi et. al. (2014) who said that motivation affects employee performance significantly and positively. The same was found in the research conducted by Sappe et. al (2014) which says that motivation affects employee performance and it is also said that motivation is something that needs to be considered in improving employee performance in a company and organization. According to Zameer et. al (2014) motivation has a positive effect on employee performance, this is because motivation is the basic approach and the basic reason for employees to join, live and work effectively, for that management must know and understand effective ways to strengthen employee performance in the company or organization.

Organizational Culture Has a Positive Impact on Increasing Employee Engagement.

In the results of testing the third hypothesis (H3), it was found that the results of the analysis support the H3 hypothesis, which is a good Organizational Culture that can increase Employee Engagement. The results of this test show that Organizational Culture has an effect on Employee Engagement. It can be seen in the Standardized Solution Diagram that Organizational Culture in this study uses 7 dimensions which include: Innovation and risk taking (BO1) of 0.82; Attention to detail (BO2) of 0.83 ; Outcome orientation (BO3) of 0.85 ; People orientation (BO4) of 0.91; Team orientation (BO5) of 0.94; Agressive (BO6) of 0.90; and Stability (BO7) of 0.92. 


\section{International Advanced Research Journal in Science, Engineering and Technology}

Vol. 6, Issue 3, March 2019

The results of research conducted by Siddhanta and Roy (2010) said that organizational culture has a direct and positive impact on employee engagement. This was also stated by McLaughlin et. al. (2017) who say that organizational culture has an influence on employee engagement, it is clear that employees prefer jobs that match their preferences and they will be motivated to be more involved with work that uses the competencies and skills they have.

\section{High Motivation Increases Employee Engagement.}

On the results of testing the fourth hypothesis (H4), it was found that the results of the analysis support the H4 hypothesis, namely high motivation can increase Employee Engagement. From the results of this test shows that motivation affects the Employee Engagement. It can be seen in the Standardized Solution Path Diagram (Figure 5.1) that Motivation in this study uses 6 indicators which include: (M1) of 0.73; (M2) of 0.71; (M3) of 0.83; (M4) of 0.79; (M5) of 0.85 ; and (M6) of 0.53 . The results of this study have the same results as the research conducted by Evangeline and Gopal (2016) wherein the study said that high motivation can increase employee engagement. This is because motivation has long been known as a very important factor for a company or organization and with good working conditions, interesting work, and a suitable salary will increase motivation, then the resulting employee engagement will also increase.

\section{High Employee Engagement Improves Employee Performance.}

In the results of testing the fifth hypothesis (H5), it was found that the results of the analysis support the hypothesis H5, which is high Employee Engagement can improve Employee Performance. Motivation in this study using 3 indicators which include: Vigor (EE1) of 0.81; Dedication (EE2) of 0.80; and Absorption (EE3) of 0.76.The results of this study are the same as the results of research conducted by Ahmed et. al (2011) who said that employee enagagement has a positive influence on employee performance. In this study, it was explained that employee engagement is the key to improving performance, in addition to effective employee engagement to improve commitment, so that later there will be a desire to achieve common goals and employee engagement will have an impact on overall employee performance. Focus and efforts need to be made especially on the factors of work environment and team relations.

\section{Employee Engagement Mediation Analysis}

Mediation variable analysis can be done through two approaches, namely: difference in coefficient and multiplication. The first approach is carried out by conducting an examination by analyzing with and without mediating variables, while the second method is done using the Sobel procedure (Hair, et al., 2006). Through the coefficient multiplication method, the results of the research hypothesis testing show the influence of the Employee Engagement mediation variable between the variables of Organizational Culture and Motivation on Employee Performance. The mediating variable of Employee Engagement is used to bridge the relationship between Organizational Culture and Motivation towards Employee Performance. Based on the results of testing the coefficient difference on the research model, it can be seen that Organizational Culture and Motivation directly influence Employee Engagement with values $(\mathrm{BO}) \mathrm{t}=3.37$ (> 1.96) and $(\mathrm{M}) \mathrm{t}=3.12$ (> 1.96), Organizational Culture and Motivation have a direct effect on Employee Performance with values $(\mathrm{BO}) \mathrm{t}=2.43(>1.96)$ and $(\mathrm{M}) \mathrm{t}=3.37(>1.96)$. So that it can be concluded that Employee Engagement can mediate the relationship between Organizational Culture and Motivation with Employee Performance. Organizational Culture and Motivation directly influence Employee Performance, and Organizational Culture and Motivation indirectly influence Employee Performance. This can be called a partial mediation analysis because it can affect directly and indirectly.

\section{CONSLUSION AND SUGGESTION}

\section{Conclusion}

The researcher concluded that: (1) Organizational Culture Has a Positive Effect on Improving Employee Performance; (2) High motivation to improve employee performance; (3) Organizational Culture Has a Positive Impact Increasing Employee Engagement; (4) High Motivation Increases Employee Engagement; and (5) High Employee Engagement Improves Employee Performance.

\section{Suggestion}

Based on the above conclusion, suggestion can be proposed as follows: (1) For company/organization, the author recommends to Head of Dinas Pariwisata Kabupaten Alor to make improvements in organizational culture, motivation and employee engagement, by regularly evaluating the organizational culture that and trying to adjust the organizational culture to the times; maintaining good relations with employees, with good relations between employees and good relations between the Head of Dinas Pariwisata Kabupaten Alor and their employees, all forms of coordination can be well conveyed; always motivate employees to be better, by offering promotions, increases in allowances or salaries; provide a comfortable work environment, so that employees can work with focus; and increase employee involvement in a job, so that employees will later feel that the ability they have can be useful for achieving 


\section{International Advanced Research Journal in Science, Engineering and Technology}

Vol. 6, Issue 3, March 2019

the goals of their institution. (2) Further researchers are expected to study more sources and references related to organizational culture, motivation, employee engagement, and employee performance so that later the results of the research can be better and the resulting research is also more accurate. The next researcher is expected to be more prepared in the collection and collection process, as well as everything so that research can be carried out properly. The next researcher is expected to be supported by interviews with sources who are competent in the study of organizational culture, motivation, employee engagement and employee performance.

\section{REFFERENCES}

[1]. Ahmed et. al. 2011. Job Involvement as Predictor of Employee Commitment: Evidence from Pakistan. International Journal of Business and Management.Vol.6 no. 4

[2]. Evangelina, E.T. dan Gopal, V. P. Ragavan. 2016. Organizational Culture and Motivation as Instigators for Employee Engagement. Indian Journal of Science and Technology.Vol. 9.

[3]. Hair, J.F. 2006. Multivariate Data Analysis. Edisi 5. Jakarta: Gramedia Pustaka Utama.

[4]. Jassim, Moh. Uddin, Rumana Huq Luva, \& Saad Md. Maroof Hossian. 2013. Impact of Organizational Culture on Employee Performance and Productivity: A Case Study of Telecommunication Sector in Bangladesh. International Journal of Business and ManagementI.Canadian Center of Science and Education.Vol.8 No.2.

[5]. Jiony etl.al. 20115.Understanding the Effect of Organizational Culture and Employee Engagement on Organizational Performance using Organizational Communication as Mediator: A Conceptual Framework.American Journal of Economics.Vol 5 no. 2.

[6]. Marciano, Paul L. 2010. Carrots and Stichs Don't Work Build a Culture of Employee Engagement with the Principles of Respect. Mexico: Mc Graw Hill.

[7]. Mathins and Jackson, R.L. 2010. Manajemen Sumber Daya Manusia, Penterjemah Jimmy Sadeli dan Bayu Prawira Hie, Jakarta: PT Salemba Empat.

[8]. McLaughlin et. al. 2017.The Impact of Organizational Culture on Employee Engagement in Saudi Banks. Journal of Human Resources Management Research. IBMA Publishing.Vol. 2017.

[9]. Robbins, Stephen P. and Judge. 2013. Organizational Behavior. 3rd Edition. New Jersey: Pearson Education.

[10]. Robbins, Stephen P. and Coulter. 2012. Management. New Jersey: Pearson Education Inc.

[11]. Sappe, Syahruddin., Yohanis Rante, Ruben Tuhumena, dan Bonifasia Elita B. 2016. Effect of Leadership on Employee's Performance Mediated by Cultural Organization, Work Commitment and Motivation.Journal of Economics and Behavioral Studies.University of Cendrawasih.Vol.8 No.2.

[12]. Shahzadi, Irum., Ayesha Javed. Syed Shahzaib P., Shagufta Nasreen, dan Farida Khanam. 2014. Impact of Employee Motivation on Employee Performances. European Journal of Business and Management.The Islamia University of Bahawalpur, Pakistan.Vol.6 No.23.

[13]. Siddhanta, Abhijit dan Roy, Debalina (gosh). 2010. Employee Engagement - Engaging the $21^{\text {st }}$ Century Workface. Asian Journal of Management Reseacrh. HR, Reliance Communications Ltd, Beadon Row, Kolkata.

[14]. Zameer et. al. 2014. The Impact of The Motivation on The Employee's Performance in Beverage Industry of Pakistan. International Journal of Academic Research in Accounting, Finance and Management Sciences.Vol 4 no.1. 